\title{
PATENT RIGHT TRANSFER THROUGH WAQF: WHAT ARE THE REQUIREMENTS?
}

\author{
Chrisna Bagus Edhita Praja ${ }^{1}$, Mulyadi ${ }^{2}$, Budi Agus Riswandi ${ }^{3}$, Kuni Nasihatun Arifah ${ }^{4}$ \\ ${ }^{1,2}$ Faculty of Law, Muhammadiyah University of Magelang \\ ${ }^{3}$ Faculty of Law, Islamic University of Indonesia \\ ${ }^{4}$ Faculty of Law, Universitas Gadjah Mada \\ E-mail: chrisnabagus@ummgl.ac.id
}

\begin{abstract}
This study aims to examine and identify criteria for patents that can be used as waqf assets. Patents are very potential as waqf asset because of a large number of patent holders in Indonesia with the requirements of productive waqf. Patents are a type of Intellectual Property with the provision of a specified period and are still a debate related to the period of waqf which is always a pro and contradiction, some scholars consider waqf property to be forever but in the waqf law is allowed a waqf property with a specified period. This research method uses a normative legal research method with a Law approach and concept approach as well as secondary data review. The Act used is the Patent Law and the Waqf Act. The results show that the patent that can be used as an waqf asset refers to the provision of waqf property which includes (1) legal ownership of the patent owner and evidenced by a patent certificate (2) is not controversial which means not in a legal dispute until in Kracht van gewijsde or not in internal conflicts for patents owned by several inventors (3) have economic value and use value so that it can benefit the community. Patents can be used as an waqf asset because in the Waqf Law it is explained that the waqf property may be for a specified period. The period in the patent waqf in the deed of the waqf pledge must be adjusted to the period of patent protection.
\end{abstract}

Keywords : rights transfer, patent, waqf asset

\section{A. INTRODUCTION}

The role of waqf in the development of economic growth can be utilized in improving the standard of living of the community (Lita, 2016). At present, the purpose of waqf is not only for the sake of worship but also for social welfare (Asmak $\mathrm{Ab}$ Rahman, 2009). As an Islamic institution, waqf have become one of the supporting developments in Islamic society. The potential for waqf in Indonesia with a generous number of Muslims is estimated at 10 million people with an average income of Rp. 500,000 , - up to Rp. 10,000,000, -, at least 3 trillion per year will be collected from waqf funds (Arif, 2012). In addition, if it is calculated from the total population of Indonesia, which amounts to more than 230 million people, and there are Muslims who are able and 
willing to represent at least IDR. 1.000.000,-/year as much as 2 percent of a total of 4.6 million people, then there will be a minimum of IDR. 4.6 billion/year (Arif, 2012).

In Indonesia, the waqf practiced is almost understood narrowly only in immovable objects. Therefore, when talking about waqf, the assumptions built are focused on objects such as land, mosques, madrassas, graves, and others (Junaidi, 2015). The idea of waqf with movable objects only appeared in 2004 with the birth of Law Number 41 of 2004 concerning Waqf. One of the interesting things in Article 16 of the Waqf Law is the inclusion of provisions stating that Intellectual Property Rights can be used as an waqf asset.

According to the Law, IPRs are categorized as movable objects that are intangible. There are 7 (seven) IPR branches/regimes consisting of Copyright, Trademark and Geographical Indications, Patents, Trade Secrets, Industrial Designs, Integrated Circuit Layout-Designs (DTLST) and Plant Variety Protection. Of the seven branches, patents are one of the branches that have the potential to be represented considering the number of patents registered in Indonesia is quite large. Recorded at the Directorate General of Intellectual Property Rights, the number of patents registered in Indonesia in the last five years up to 2018 amounted to 41,230 patent registrants with Non-tax revenue (PNBP) statistics of IDR. 1,110,850,453,076. The number of patents registered and potential to be represented is not followed by the Government's efforts in making technical instructions and the IPR implementation guidelines as waqf asset. So, the existence of Article 16 of the Waqf Law which contains provisions that IPR can be used as an object of waqf seems futile.

Until now the practice of waqf with the object of IPR is still a bit carried out by the parties, both those who authorize (wakif) and those who manage the assets of waqf (nazir) even though it has been regulated in the Waqf Law that IPRs can be used as waqf. The cause of the lack of registration of IPRs as an waqf asset is due to ignorance of the parties and the implementation of regulations which make it difficult for the Indonesian Waqf Board to accept the IPR waqf and regulate technically and administratively about the IPR waqf.

Other problems that arise in the representation of the IPR object are related to the period. Some scholars argue that the representation is forever. (al-kabisi, 2004) But in Article 1 of Law Number41 of 2004 concerning Waqf, it is explained that the period of waqf is forever or in a specific time according to its importance. The change of waqf which was initially waqf absolutism forever became a period of waqf that is relative to 
the juridical considerations of maqashid syar"iyyah means the benefit of facilitating the waqf, the basis of community economic empowerment, and sociological society. Provisions on Islamic law if a waqf is given within a specified period, namely that the issue of waqf includes the environment of fiqh, not shari'ah. This means that all the rules and provisions relating to waqf are only jurisprudence which is the result of the human perspective which is subject to sociological determinants. The substance contained in the regulations of Article 1 paragraph (1) of Law Number 41 of 2004 is the value of the benefits of waqf. If you see from the disagreement, the IPR is included in the waqf regime within a specified period by the benefits. Problems arise again related to the assessment of the value of profits from patents and simple patents as well as the legal legitimacy of those who have the right to assess the benefits of patents and simple patents that are worthy of being waqf.

\section{B. PROBLEM STATEMENT}

In accordance with the theme above, This research focuses on the requirement for patents that can be used as waqf asset about the achievement of waqf goals, namely social welfare due to the large number of patent owners with large PNPB.

\section{RESEARCH METHODS}

This study uses the Normative Legal Research method with primary and secondary data collection. The approach used is the Statue Approach and Conceptual Approach. Approach to Statue reviewing the Waqf Law and Patent Law. The Concept Approach is carried out by examining the doctrines of experts relating to the legal issues being studied. The licensed material used in this study is primary legal material, namely the Laws and Regulations relating to the legal issues under study. The second legal material is secondary legal material, namely books, legal journals, and information obtained from the Directorate General of Intellectual Property at the Ministry of Law and Human Rights of the Republic of Indonesia, the Indonesian Waqf Board as well as from informants / nazir in the Office of Religious Affairs (KUA) of all sub-districts in Magelang City.

\section{DISCUSSION AND RESEARCH RESULT}

1. Juridical Review Patent as a Waqf Asset 
In Law Number 41 of 2004 concerning waqf, explained that the waqf is a wakif legal act to separate and surrender some of his property to be used forever or for a specified period under his interests for worship and general welfare according to shari'ah. Law Number 41 of 2004 concerning the Waqf was ratified on October 27, 2004. All regulations regarding the previous repayments were considered to be valid as long as they were not in conflict with and or had not been replaced with the new rules under this law. Birth of Law Number 41 of 2004 concerning Waqf is directed to empower waqf which is one instrument in building the socio-economic life of Muslims. The importance of the presence of this law, in addition to the interests of worship, is also momentum for the productive empowerment of waqf for social purposes, because it contains a comprehensive understanding and management pattern of empowering modern waqf potential.

IPR is seen as one of the huquq maliyyah (property rights) that gets legal protection as well as a mall (wealth) if it does not conflict with Islamic law. This was confirmed in the MUI fatwa Number 1 / MUNAS VII / MUI / 15/2005 concerning Protection of Intellectual Property Rights dated July 29, 2005, which states that IPR is a property and can be used as an waqf asset. Based on the Hanafiyah and Syafi'iyah schools, immovable objects can be represented. (al-kabisi, 2004) In addition to the IPR Law namely Law Number29 of 2000 concerning Protection of Plant Varieties, Law Number 31 of 2000 concerning Industrial Design, Law Number 32 of 2000 concerning DTSLT, Law Number 3 of 2016 on Patents, Law Number 15 of 2001 on Trademarks, and Law Number28 of 2014 concerning Copyright states that the transfer of IPRs can be through representatives. More detailed in Article 74 paragraph (1) letter d of Law Number 13 of 2016 concerning Patents adding assignment of Patents by waqf. "The right to patent can be transferred or transferred in whole or in part because:

1. inheritance;

2. grant;

3. testament;

4. waqf;

5. written agreement; or

6. other reasons are justified based on the provisions of the legislation

Juridically, Intellectual Property is associated with ownership of rights to movable objects, immovable objects, tangible or intangible objects. The legal 
perspective considers IPRs to be classified as private property rights arising from natural human rights because IPRs are similar to other property rights that can be maintained from the power of anyone who is not entitled. Because the history of the birth of IPR is a new form of the development of common property rights or movable objects that are intangible, the intellectual property rights arise as a form of appreciation for intellectual activities manifested in something new or original, both in the field of literary and scientific technology and industrial. Equation with other property rights in general, namely the material rights can be transferred to other people in various ways or legal events including waqf.

The core teaching contained in the waqf is the spirit of upholding social justice through the provision of assets for the benefit of society. So even though waqf is a benevolent charity that is recommended, but has a very high impetus for the creation of equal welfare of the people. More than that the scholars categorized waqf as qadaqah jāriyah whose rewards continued to flow even though the deceased person had passed away so that the continuity of reward was obtained because the aspect of waqf was felt by the community. Whereas in positive law explained in Article 6 of the Waqf Law, waqf are carried out by fulfilling the following elements of waqf:

1. Wakif;

Parties who endow their property include individuals, organizations, legal entities. Wakif in patent rights means that the legal owner of the patent is proven by ownership of a patent ownership certificate issued by the Directorate General of Intellectual Property Rights of the Ministry of Law and Human Rights Indonesian Republic.

2. Nazhir;

Nazhir has the task of administering waqf property, managing and developing waqf under its purpose, function, and designation, supervising and protecting waqf property, and reporting on the implementation of duties to the Indonesian Waqf Board. Nazhir in the Patent Right Representative is Nazhir at the BWI level at the Central and Regional levels.

3. Waqf Asset

Waqf Asset is the property that has long-term durability and long-term benefits and has economic value according to the sharia that is represented by the waif. According to the provisions of Article 15 the Waqf Law can only be represented if it is owned and controlled by Wakif. According to the scholars, the validity of waqf 
is determined by the property that is represented, so that the object must fulfill the following conditions: (al-kabisi, 2004)

a) Waqf assets must have (valuable) value;

b) clear form;

c) the property of the person who forgives (wāqif);

d) the object being represented is immovable, such as land or objects that are adapted to the existing waqf habits. Patent rights can be used as an waqf asset because the patent rights are legal and clear in shape and have a price value. If at the time of registration of both a patent and a simple patent, it has no economic value and price value, it can still be registered with BWI. According to the statement of the Executive Director of the Indonesian Waqf Board, Drs. H. Achmad Djunaedi MBA, that all objects that previously did not have economic value, but have the potential to have value benefits can still be registered as waqf.

According to Hanafiyah scholars, patents include movable objects; this is permissible because the material of the moving object follows immovable objects, namely rights. In addition, patents which are always in the form of objects related to technology can also bring knowledge to people who use these objects. The value of the benefits of the patent which will later become the value of the representative is in addition to the economic value of the Patented Representative. The economic value of a patent is patent can be sold, produced and licensed.

4. Waqf Pledges;

Waqf pledges were carried out by waif to Nazhir before Officials Pledge Deed of Waqf (PPAIW) witnessed by 2 (two) witnesses. The pledge as mentioned above is stated verbally or in writing and is stated in the deed of an waqf by PPAIW. Furthermore, in Article 18 the Waqf Law states that in the case of wakif cannot declare a waqf pledge orally or cannot be present in the implementation of the waqf pledge for reasons justified by law, the waif can appoint its proxy with a power of attorney strengthened by 2 (two) witnesses.

5. Allotment of Assets Waqf;

Waqf property is intended for the welfare of the people.

6. Waqf Term.

Regarding the period of waqf, there are still pros and cons among ulama. In Islamic law (the definition of Islamic law in question is Compilation of Islamic Law (KHI) and mazhab fiqih) waqf is to release ownership of property which can be used 
without reducing the material to be handed over to individuals or groups (organizations) to be used for purposes that are not contrary to shari'a", forever. (Hukmiah, Abbas, \& Ismail, 2015) But according to Abu Hanafiyah, the waqf of patent rights is permitted because the patent has a predetermined period. The existence of a waqf with a specified term is affirmed in Law Number 41 of 2004 concerning Waqf, in Article 1 it is explained that the waqf is a wakif legal act (waqf) to separate and/or surrender some of his property to be used forever or for a specified period in accordance with his interests. If you see from the legal rules regarding the waqf, then Patent Rights can be represented as a type of waqf over a certain period. Because both Patents and simple Patents cannot be extended. A patent with a period of twenty years from the date of receipt and simple patent ten years from the date of receipt.

Waqf are divided into various types, namely if viewed from the use of the property of waqf are divided into direct waqf or waqf that process waqf processing provides direct service to those who are entitled (Waqf mosque, school, hospital, tree waqf taken by fruit, waqf of vehicles, animal waqf and waqf of worship equipment, book waqf, weapons waqf, mushaf waqf, land, and clothing) and productive waqf, namely waqf from professional waqf processing to increase the value of the benefits of waqf (waqf of money, shares, Islamic bonds, state securities, property rights of flats, as well as waqf of IPRs) (Abdurohman Kasdi, 2017) Whereas the time limit of waqf is divided into waqf mu'abbad (forever) examples are land and buildings with land. As well as mu'aqqat waqf (temporary or with a certain period). Referring to the type of waqf, the patent is included in the criteria of the muaqqaya waqf, namely the waqf that is limited by the time period not because it is stipulated in the waqf vow which is pronounced wakif, but the IPR waqf is limited by the Law. (Islamiyati, 2017)

So the conclusion is juridically both in Islamic law and positive law in Indonesia, patents can be represented. Economic value can be measured from the patent object, namely the use value, selling value, and use value that can be used for the welfare of the people. Assessment of the economic value of IPRs is also still being debated. If all this time the Appraiser for the assessment of intangible assets refers to PPP-4 (guideline for Indonesian Assessment Practices 4, then for assessors in IPRs is still a debate. This is also according to Dr. Marvel, Head of Public Relations of the Directorate General of IPR (DGIP) suggesting the need for coordination between DGIP and Bank Indonesia and BWI to assess the economic value of IPRs. (Dr. 
Marvel, 2018) In addition to the valuation of the value of patent rights, patents that will be used as waqf must meet the criteria of waqf property, because if the patent does not have these elements, then fulfill the aspects of the object that can be represented Patent rights that can be used as waqf are patents that do not conflict with the provisions of Islamic religion. (Islamiyati, 2017) In addition to the economic value of social benefits from patents can be used as a basis for representation. The consequence of the transfer of rights, the right of the property attached to IPR with the owner's moral rights and the economic value that results from the value of intellectual property is certainly also switched, but the IPR regime regulates that Moral Rights are inherent rights to IPR owned forever. (Mastur, 2012)

\section{Patent Requirements for Waqf Asset}

The provisions of laws and regulations for Patents are regulated in Law Number 13 of 2016 concerning Patents which have been officially valid after being signed by President Joko Widodo in August 2016. There are many changes to the latest Patent Law compared to the previous Act, namely Law Number 14 of 2001. One of the changes is Law Number 13 of 2016 as stipulated in Article 20 regulates more firmly regarding the obligation of the holder of a patent to make products in Indonesia, something less done by Law Number 14 of 2001. The Government's move to revise Law Number 14/2001 into Law Number 13/2016 is an effort to improve the provisions stipulated in the Patent Law to provide better protection to inventors or right holders and bring more significant benefits to human welfare. In addition, another goal of changing the Patent Law is that the new Patent Law is not outdated and can follow international developments. Although IPRs are known for their concept of capitalism because IPRs contain monopoly teachings of individual rights, IPRs can also be used on social aspects, because they provide the benefit or goodness and benefit of society in general as long as they do not conflict with Islamic law. This is under the principle of Islamic economic law which explains that property rights function socially, meaning that even in the IPR there is a right for the poor at $2.5 \%$. IPR for waqf purposes is an example of the use of the property for social purposes because the waqf is a legal action to divert individual interests towards the interests of the people (Mardani, 2010).

Patents ranked third as registered Intellectual Property. Patent owners in Indonesia within the last five years amounted to 41,320 registrants with PNBP from 
patents within the five-year period of Rp. 1,110,850,453,076. Legal protection against patented inventions is given a specified period. During this period, the inventor can carry out his own patented invention or submit to another person to carry out his invention. The patent protection period for a patent is 20 (twenty) years from the date of receipt and cannot be extended. While a simple patent is granted for a period of 10 (ten years) and cannot be extended. Seeing the patent with this period and cannot be extended, in the case of a waqf, a simple patent and patent belongs to the type of mu'aqqat bi ghayrihi waqf or waqf with a certain period. (Hidayah, 2012) Protection of a simple Patent or Patent period cannot be extended. The basis of the government's consideration to provide simple patent protection is shorter because in general the product or tool protected in a simple patent is obtained in a relatively short time, in a simple way, a cheaper cost, and a simple technology. So that the period of protection is considered sufficient to obtain reasonable economic benefits (Hidayah, 2012)

In an interview conducted with the Directorate General of Human Rights Directorate General of IPR, Dr. Marvel explained that Patents in Indonesia are very potential as waqf asset. Besides that Patent is one form of technology literacy from a country. The economic value of patenting waqf is that the patent owner can grant his patent rights which later the waqf recipient can produce patents that can produce economic value from the patent. Technological advances have had an impact on human civilization. In the past few decades the direction of development has been based on industry and technology that have produced high added value. Indonesia's agreement to realize the idea of AFTA (Asean Free Trade Area), WTO (World Trade Organization) and APEC (Asia Pacific Economic Cooperation), has shown the government's seriousness in supporting an open economic system, this must be accompanied by increased competitiveness of companies to individuals to participate in it. However, with the era of free trade, there is an issue that is intellectual property rights, because intellectual property rights are inseparable from the world free trade agreement package. So that inventors in Indonesia have an excellent opportunity to participate in the nation's technological development. If all inventors endorse all or part of their patents, it is indeed not impossible for the patent to later be developed as a productive waqf for the benefit and welfare of the people. (Dr. Marvel, 2018)

The expansion of the scope of waqf objects that make IPRs as waqf property is one form of legal reform contained in Law Number 41 of 2004 concerning Waqf. The change aims to make waqf as one of the instruments to provide welfare for the 
Muslim community because it makes waqf as a medium to create economic justice, develop a social security system, reduce poverty, and can improve the feasibility of health care facilities and public service facilities. This must be welcomed, meaning that by regulating the transfer of Patents through waqf is expected to stimulate inventors to validate their invitations, and to foster enthusiasm for the Muslim community to make inventions which can later be used as waqf. Because if viewed from a social perspective, mainly to improve the general welfare, it is deemed necessary to increase the role of waqf as a religious institution that is not only aimed at providing various means of worship and social but also has economic power. Such economic strength has the potential as a means to advance public welfare so that it needs to be developed under the principles of shari'a. Even now many Islamic universities and Madrasas are expected to grow new inventions. (Henry, 2016)

It can be concluded that a patent that can be transferred to its rights through a waqf is a patent with legal ownership in which the ownership of the patent is evidenced by a patent certificate issued officially by the Directorate General of Intellectual Property Rights. The document contains the name of the patent inventor which later the certificate is authentic evidence in the inventor's legal ownership. Besides, the patent to be represented is not allowed to contain anything controversial, meaning that it does not violate Islamic law and is not in dispute both from the inventors and the dispute process in court before obtaining a permanent legal decision. The third provision is that the patent contains economic value and benefits. Determination of economic value is related to economic rights owned by the Patent Inventor. Economic rights are inherent in patents because royalties generated from these patents can be used for the benefit of society in the form of productive waqf. In addition to the economic value of the patented patent, it certainly has useful use values as well. Because if the patent does not have these elements, then it does not fulfill the element of property that can be represented. In addition to these three things, in the waqf pledge deed must be stated on the period of waqf of Patent Rights, namely following the 10-year Patent Law for a simple patent and 20 years for a patent from the date of receipt of the patent and the period cannot be extended. 


\section{E. CLOSING}

\section{CONCLUSION}

Based on the description in the previous sections, it can be concluded that juridically the transfer of patents through waqf does not conflict with Islamic law, namely the opinion of Hannafiyah scholars who allow waqf with movable objects with the rights inherent therein including patent rights. Positive law. Article 74 paragraph (1) letter d of Law Number 13 of 2016 concerning Patents also allows the transfer of patents through waqf. In the transfer of patent rights through waqf, of course, must pay attention to the provisions in the waqf legal conditions, namely the existence of waqf, nazhir, waqf, waqf pledges, allotments of waqf, and period. Patent criteria as waqf are patents that follow the requirements of property that can be used as waqf. Patent criteria include (1) patents that are legally owned by the patent owner as evidenced by a patent certificate issued by the Directorate General of Intellectual Property Rights (2). Patents do not contain any controversy that violates Islamic Law and not in a reasonable internal dispute from the inventor or in the dispute process in court before obtaining a permanent legal decision. (3) The patent has economic value and benefits. Concerning the patent term of twenty years for patents and ten years for simple patents, of course, patent rights are included in the productive waqf with a temporary period. Waqf property must certainly have a price value in the form of economic value and value of benefits. The economic value in the Patent is obtained from the sale value, the production value of the patent itself obtained from the economic rights of the patent owner. While the value of benefits is obtained from the technology results of the invention which later can be used as a charity for the benefit of the people.

\section{SUGGESTION}

Intellectual Property Rights especially patents have great potential as waqf assets. However, the absence of technical provisions in the implementation of waqf with patent assets makes this potential seem futile. The government must immediately ratify the Waqf Bill along with the rules of implementation. In addition, it is necessary to coordinate with Bank Indonesia about assessing the economic value of intellectual property. Another thing that can be done by the government together with BWI is to 
educate Nazhir at the regional level. The results of this study are expected to be one of the guidelines in making technical regulations.

\section{F. ACKNOWLEDGMENTS}

The research was supported by Institute for Research, Development and Community Service (LP3M) Universitas Muhammadiyah Magelang through a Research on Revitalizing Institutional Vision (PRVI) Grant. This work is also supported by the Research Division of Universitas Muhammadiyah Magelang for Monitoring and Internal Evaluation facility. Researchers are grateful to all the institutions that have supported this research and to reviewers.

\section{BIBLIOGRAPHY:}

\section{Books:}

Abdurohman Kasdi, 2017, Fiqih Wakaf Klasik Hingga Wakaf Produktif, Idea Press:Yogyakarta

al-kabisi, M, 2004, Hukum Wakaf (Kajian Kontemporer Pertama dan terlengkap tentang Fungsi dan Pengelolaan Wakaf serta Penyelesaian atas Sengketa Wakaf, IIMAN Press: Jakarta.

Dr. Marvel, 2018, Paten dan Potensinya di Indonesia, Ditjen HKI Kemenkumham: Jakarta.

Esmi Warassih, 2011, Pranata Hukum Sebuah Telaah Sosiologis, Badan penerbit Universitas Diponegoro: semarang.

Henry, S, 2016, Wakaf Hak Kekayaan Intelektual. (B. A. Riswandi, Ed.) (1st ed.). UII Press: Yogyakarta.

Hukmiah, N., Abbas, S., \& Ismail, I, 2015, WAKAF DALAM JANGKA WAKTU

TERTENTU ( Suatu Analisis terhadap Undang-Undang Nomor 41 Tahun 2004 tentang Wakaf dan Hukum Islam ), 3(1), 55-65.

Junaidi, A, 2015, Wakaf Uang sebagai sistem Ekonomi Islam yang Berkeadilan, ZISWAF, 2(1), 199-216.

Lita, H. N, 2016, Wakaf Hak Kekayaan Intelektual. (B. A. Riswandi, Ed.) (1st ed.). UII Press: Yogyakarta

Mardani, 2010, Hukum islam, pengantar Hukum Islam di Indonesia,Pustaka pelajar: Jakarta.

\section{Journals:}

Arif, M. N. R. Al, Wakaf Uang dan Pengaruhnya terhadap Program Pengentasan Kemiskinan di Indonesia. Indo-Islamika, 2(1), 2012. (Retrieved from http://journal.uinjkt.ac.id/index.php/indo-islamika/article/view/1649)

Asmak Ab Rahman, Peranan Wakaf Dalam Pembangunan. Shariah Journal, 17(1), 2009 
Hidayah, K, Perlindungan Hak Paten Dalam Kajian Hukum Islam Dan Peran Umat Islam Dalam Bidang Iptek. De Jure : Jurnal Hukum Dan Syar'iah, 4(1), 2012.

Islamiyati, Hak Kekayaan Intelektual ( HKI ) Sebagai Harta Wakaf ( Analisis Pasal 16 UU No . 41 Tahun 2004 tentang Wakaf ). Jurnal Hukum Ekonomi Islam, 1(1), 2017.

Mastur, Perlindungan hukum hak kekayaan intelektual dibidang paten. Jurnal Ilmiah Ilmu Hukum QISTI, 6(1), 2012 